\title{
The Impact of Engaged Couples' Sexual Knowledge and Beliefs on Their Beliefs and Attitudes Towards Marriage
}

\author{
Nişanlı Çiftlerin Cinsellikle İlgili Sahip Oldukları Bilgi ve İnanışlarının Evliliğe \\ Yönelik İnanç ve Tutumlarına Etkisi
}

\author{
Seyhan Çankaya ${ }^{* 1}$, Hacer Alan Dikmen
}

\begin{abstract}
Aim: This research aims to determine the influence of sexual knowledge and beliefs of engaged couples on their marriage beliefs and attitudes. Methods: This descriptive study was conducted between October 2018 and December 2018 in Family Health Centers (FHCs) located in Konya city centre. The sample of the study is composed of 402 couples who have agreed to participate in the research. The data have been collected through the Data Collection Form (DCF), the Form of Beliefs Related to Sexual Information (FBRSI) and the Scale of Beliefs and Attitudes Towards Marriage - Health Belief Model (SBATM-HBM). The questionnaires have been individually applied to the couples in separate rooms. Results: The mean scores of the engaged couples on the FBRSI and SBATM-HBM are $24 \pm 5.1$ and $73.7 \pm 10.7$, respectively. When the factors affecting the sexual knowledge levels of engaged couples are examined, it is noticed that the mean scores of FBRSI and SBATM-HBM for those who are over 26 years old, have high school degree or above, work in an income-generating business, decide to get married with a mutual consent, have a mother with a high school degree or above, and have knowledge of sexual and reproductive health are higher $(\mathrm{p}<0.05)$. Besides, it has been found that one-third of the couples have knowledge related to sexuality and reproductive health; however, they have received extremely little information from the healthcare workers. Furthermore, it has been determined that as the mean scores of FBRSI increase, the mean scores of SBATM-HBM increase, as well, and there is a positive relationship between them. According to the results of Stepwise Multiple Regression Analysis, it has been discovered that those who are 25 years old or below, have no knowledge about sexual and reproductive health, have mothers with primary school degree or below, and have low FBRSI mean scores have a negative effect on their beliefs and attitudes towards marriage $(p<0.05)$. Conclusion: Factors such as age, educational background, gaining sexual knowledge, mother's educational background, and knowledge and beliefs related to sexuality have a considerable effect on the beliefs and attitudes of the engaged couples towards marriage.
\end{abstract}

Key words: Marriage beliefs and attitudes, sexual knowledge, sexuality, premarital period, engaged couple

\section{ÖZET}

Amaç: Nişanlı çiftlerin cinsellikle ilgili sahip oldukları bilgi ve inanışlarının evliliğe yönelik inanç ve tutumlarına etkisini belirlemek.Yöntem: Bu araştırma tanımlayıcı tiptedir. Araştırma Konya il merkezinde bulunan Aile Sağlığı Merkez'lerinde Ekim 2018Aralık 2018 tarihleri arasında gerçekleștirildi. Araştırmanın örneğini araştırmaya katılmayı kabul eden 402 çift oluşturmaktadır. Veriler soru formu ve Cinsellikle İlgili Bilgi ve İnanışlar Formu (CIBİF) ve Evliliğe Yönelik İnanç ve Tutumlar Ölçeği- Sağlık İnanç Modeli (EYİTÖSiM) kullanılarak toplanmıștır. Soru formları çiftlere ayrı mekânlarda bireysel olarak uygulandı.Bulgular: Nişanlı çiftlerin CiBIF ve EYITÖ-SIMM Ölçeği puan ortalamaları sırasıyla $24 \pm 5.1$ ve $73.7 \pm 10.7$ 'dir. Evlilik hazırlığı yapan çiftlerin cinsel bilgi düzeylerini etkileyen faktörler incelendiğinde, 26 yaşından büyük olanların, lise ve üzerinde öğrenime sahip olanların, gelir getiren bir işte çalışanların, tanışıp anlaşarak evlenmeye karar verenlerin, annesinin eğitim durumunun lise ve üzerinde olanların, cinsel ve üreme sağlığı konusunda bilgi alan nişanlı çiftlerin EYITÖ̈-SIMM puan ortalamalarının daha yüksek olduğu belirlendi $(\mathrm{p}<0.05)$. Araştırmada çiftlerin üçte birisinin cinsellik ve üreme sağlı̆̆ı konusunda bilgi aldıkları, ancak bu bilgiyi çok düşük oranda sağlık personelinden aldıkları belirlendi. CỉBİF puan ortalamaları arttıkça, EYITÖ-SIM puan ortalamalarının arttı̆̆ı ve aralarında pozitif yönde bir ilişki olduğu belirlendi. Stepwise Çoklu Regresyon Analizi sonucuna göre, çiftlerin 25 yaş ve altında olanların, cinsel ve üreme sağlı̆̆ konusunda bilgi almamış olanların, anne öğrenim durumunun ilköğretim ve altında olanların ve CIBBIFF puan ortalaması düşük olanların evliliğe yönelik inanç ve tutumlarını negatif yönde etkilediği bulunmuştur $(\mathrm{p}<0.05)$. Sonuç: Evlilik hazırlığı yapan çiftlerin, evliliğe yönelik inanç ve tutumlarını; yaş, öğrenim durumu, cinsellikle ilgili bilgi alma durumu, anne öğrenim durumu, cinsellikle ilgili bilgi ve inanışlar gibi faktörler etkilemektedir.

Anahtar Kelimeler: Evlilik inanç ve tutumu, cinsel bilgi, cinsellik, evlilik öncesi dönem, nişanlı çift

Received Date: 29.04-2019, Accepted Date: 13.06-2019

*1 Selcuk Univeristy

*Selcuk Univeristy

*Address for Correspondence / Yazışma Adresi: Seyhan Çankaya, Selcuk Univeristy

E-mail: seyhane32@.gmail.com

Çankaya S., Dikmen H.A., The Impact of Engaged Couples' Sexual Knowledge and Beliefs on Their Beliefs and Attitudes Towards Marriage.TJFMPC, 2019;13 (4): 427-436.

DOI 10.21763/tjfmpc.550471: 


\section{INTRODUCTION}

The premarital period is a developmental stage with its own dynamics, specific expectations and needs. In this period, individuals need to know each other, their relationships before getting married and need information about sexual and reproductive problems. 1,2

Individuals' sexual perspectives are profoundly affected by the culture, religious beliefs, value judgments, false sexual information and beliefs of the society. 3 Cultural structure of Turkey prohibits and restricts sexuality and allows only under certain circumstances. In such cultures, except reproductive purposes, sexuality is repressed so that leaving the youth uninformed and prohibiting premarital sexual intercourse strictly. 4 Within this context, the patterns and judgments forming the basis of gender in society also affect flirting, engagement and marriage of to a great extent. In terms of reproductive and sexual health, the information needs of couples about to marry are essentially shaped by perceptions and views on these issues and by gender roles in the society. 5 Gender roles create significant differences and inequalities between man and women in marriage and family life as well as in business and social life. In studies, it has been revealed that women adopt more egalitarian views about working life and marital life while men are expected from women to carry out traditional roles.6,7 Since sexual issues cannot be talked and discussed in the family, in the neighbourhood, in the school, and since the problems cannot be expressed freely, young people cannot get adequate and qualified information about sexual life. Therefore, young people generally obtain their sexual knowledge from their friends. Since the accuracy of this knowledge is controversial they may come up with unhealthy solutions for their problems.8 Sexual ignorance, more importantly, false information and beliefs cause the rise of sexual problems in society. Studies, showed that the married couples experiencing sexual problems are likely to have insufficient sexual knowledge9 and that their marital adjustment is rather low.3, 10 Also, in the literature, it is obviously stated that happiness in marital life depends on sexual satisfaction. 3 there are several factors that determine sexual attitudes and behaviors including family, neighbourhood, subculture and social structure, traditions, religious beliefs and moral attitudes. In many cases, only sociocultural causes play a major role in the emergence of sexual dysfunction.1,11 Although the number of studies on sexuality and marital adjustment in our country and in the world has been increasing in recent years, studies investigating the sexual knowledge and beliefs of couples preparing for marriage and their beliefs and attitudes towards marriage are limited.11,13,14,16 For this reason, with this study, we intend to determine the impact of sexual knowledge and beliefs of engaged couples, who are getting prepared for marriage, on their marriage beliefs and attitudes.

\section{Research Questions}

In this research, the following issues have been clarified:

1. Do descriptive characteristics of couples are related with their sexual knowledge and beliefs, and their marital beliefs and attitudes?

2. Is there a relationship between couples' mean scores of sexual knowledge and beliefs, and their mean scores of marital beliefs and attitudes?

3. Do the sexual knowledge and beliefs of couples and their sociodemographic characteristics have any relationship with their marital beliefs and attitudes?

\section{METHODS}

\section{Type of Study}

This research is a descriptive and cross-sectional study.

\section{Characteristics of the Research Setting}

The study has been conducted in Family Health Centers (FHC) in Konya province centre. There are three municipalities in the centre of Konya, and one Family Health Center (FHC) has been selected from each municipality by the method of drawing. The FHCs, where the research has been conducted as a result of the draw, are 17 FHC (in Selçuklu Municipality), 29 FHC (in Meram Municipality), and 15 FHC (in Karatay Municipality). The engaged couples, applying to the laboratories in these FHCs in order to have legally compulsory blood tests before marriage, have been recruited in the study. 


\section{Universe and Sample of the Research}

The study's universe was 513 couples applying to selected FHCs between October 2018 and March 2019. Couples who have been eligible and agreed to participate in the study have been taken into the study, without creating a particular sample for the research. A group of couples have not been included due to not agreeing to participate $(\mathrm{n}=62$, $12 \%)$ and not having sufficient time $(\mathrm{n}=49,9.7 \%)$. A total of 402 couples ( $78.3 \%$ of the universe) participated in the study.

The engaged couples who,

- have been volunteered to participate in the research,

- could speak and understand Turkish,

- have not had any sight and hearing problems, and cognitive impairment,

- have given answers to the questions, have been included in the research are included in the study.

\section{Data Collection}

The data have been collected by the researchers via a questionnaire by interviewing couples who applied to the selected FHCs between October 2018 and March 2019 and volunteered to participate in the study. To ensure privacy of the couples, they have been gathered in a private rooms at the FHC and filled forms in separate rooms so that they could not influence each other.

\section{Data Collection Tools}

Research data have been collected through the Data Collection Form (DCF), the Form of Beliefs Related to Sexual Information (FBRSI) and the Scale of Beliefs and Attitudes Towards Marriage Health Belief Model (SBATM-HBM). The questionnaire and scales were filled out in nearly 15 min time by each participant.

\section{General Information Questionnaire}

A 17-items questionnaire prepared by the researchers in accordance with the related literature.1,2,14,16,17 The questionnaire consisted of questions about the socio-demographic characteristics of the couples, how the couples have met as well as educational background, the marriage style and the marriage contract style of the couples' parents and also inquire previous experiences on the sexualty and reproductive health. Additionaly, there are questions that address the concerns about where the couples have learnt about sexuality and reproductive health firstly, whether they have received premarital sexual education, whether they feel under pressure about sexuality, and lastly, whether or not they agree with the idea of "giving sexual education to young people cause early sexual activity".

\section{The Form of Beliefs Related to Sexual Information (FBRSI)}

The Form of Beliefs Related to Sexual Information (FBRSI), developed by Senturk in 2006 to determine the knowledge and beliefs of the couples about sexuality.12 The FBRSI is composed of a list of expressions covering the false information and beliefs. It consists of 34 items in total. The answers to each item are scored as "True" or "False". Each correct answer is counted as "1" point and each wrong answer is counted as " 0 ". The total score of the form varies between 0 and 34 points. As the score gets closer to zero, the knowledge is considered to be insufficient, and as the score approaches 34 points, it indicates that sexual knowledge is saficient.

\section{The Scale of Beliefs and Attitudes Towards Marriage - Health Belief Model (SBATM-HBM)}

The scale, which was originally developed by Sullivan et al.13 to evaluate the beliefs and attitudes of individuals planning to marry in America. It consists of four sub-dimensions (the perceived benefits, the perceived severity, the perceived susceptibility, the perceived barriers) and contains 23 items in total. The number of categories in the scale is 5 in total, and the items are scored between 1-5 points. The beliefs and attitudes about the subject involves reaction categories ranging from "I totally agree" (with "undecided" category in the middle) to "I do not agree at all". As the number of points increases, individuals' attitudes and beliefs increase positively. Vural and Temel14 (2007) studied validity and reliability of the Turkish version of SBATM-HBM, and found Cronbach's alpha of 0.72 . 


\section{Ethical Considerations}

At the beginning of the research, research ethics committee approval has been granted by the Faculty of Health Sciences of Selçuk University (Ethics permit no: 1679). Moreover, the couples have been informed about the purpose of the research clearly, and their verbal approvals for the participation have been taken. Before the data collection, the couples have been informed about the purpose and requirements of the research. While informing, the couples have been informed in detail that voluntary participation in the study is a fundamental requirement and that their sincere answers will contribute to the investigation and they will be kept confidential and evaluated only as scientific data. Moreover, they have also been told that they may stop filling out the questionnaire whenever they wish if they find the questions annoying, and that their names must not be written on the forms to keep the identity information confidential.

\section{Data Analysis}

Statistical Package for the Social Sciences (SPSS) 20.0 package program has been used for the evaluation of the data. The normality analysis of the data has been done with the Kolmogorov Smirnov Test. The descriptive statistics of the data with normal distribution have been calculated with mean, standard deviation and percentage. Mean differences have been calculated by one-way analysis of variance (ANOVA) and the significance test of the difference between the two means (independent sample t-test). When the group number was more than two, Post-Hoc Tukey HSD tests were performed to find out the group from which the difference is originated. The relationship between the two continuous variable was assessed by Pearson correlation analysis. Stepwise multiple linear regression analysis was used to determine factors affecting SBATM-HBM scores. Stepwise multiple regression analysis was performed to evaluate the independent associations existing between the potential risk factors and SBATMHBM scores. Independent variables that were significant at the $\mathrm{p}<0.05$ level in bivariate analysis were included multivariate analysis to control for confounding factors in regression models. 15

\section{RESULTS}

It was found that $60.4 \%$ of the couples were at the age of 25 and below, $77.9 \%$ had high school or higher education degree, $51.5 \%$ were working and $60.2 \%$ of them got engaged with mutual consent. Examining the mean scores of couples getting prepared for marriage, they have been found as 22,7 $\pm 4,9$ for females and $25,3 \pm 5$ for males on the FBRSI, and they have been determined as $72,9 \pm$ 9,9 for females and $74,6 \pm 11,4$ for males on the SBATM-HBM. In statistical analysis, although mean scores of FBRSI for males are higher than for females, there is a statistically significant difference on the basis of gender $(\mathrm{p}<0.05)$. As for the SBATM-HBM results, there is no statistically significant difference between the mean scores of males and females although mean scores for males are found to be higher (Table 1).

In the study, the mean scores of FBRSI and SBATM-HBM have been found to be higher and statistically significant $(p<0,05)$ for those couples who are older than 26 , have high school and above education degree, working in an incomegenerating business, decided to get married with a mutual consent, have mothers with a high school degree and above, and have been informed about sexual and reproductive health before. Furthermore, the mean scores of FBRSI and SBATM-HBM were significantly low for couples who have feelings of oppression and difficulties in speaking about the sexual issues ( $p<0,05$, Table 1). Mean scores of FBRSI and SBATM-HBM showed no significat difference for variables of agreement with "giving education to young people on sexuality and reproductive health causes early sexual activity" idea, father's education level, marriage and marriage contract type of parents and source and place of the information about the sexual and reproductive health is provided ( $p>0.05$, Table 1$)$. 
Table 1. Comparison of descriptive characteristics of the couples with subdimensions of the form of Beliefs Related to Sexual Information (FBRSI) and the scale of Beliefs and Attitudes Towards MarriageHealth Belief Model (SBATM-HBM)

\begin{tabular}{|c|c|c|c|}
\hline & $\mathrm{n}(\%)$ & $\begin{array}{l}\text { FBRSI } \\
\text { Mean } \pm \text { SD }\end{array}$ & $\begin{array}{l}\text { SBATM-HBM } \\
\text { Mean } \pm \text { SD }\end{array}$ \\
\hline $\begin{array}{l}\text { Gender } \\
\text { Woman } \\
\text { Man }\end{array}$ & $\begin{array}{l}201(50) \\
201(50)\end{array}$ & $\begin{array}{l}22,7 \pm 4,9 \\
25,3 \pm 5 \\
t=-5,190 \\
\mathbf{p}<\mathbf{0 , 0 0 1}\end{array}$ & $\begin{array}{l}72,9 \pm 9,9 \\
74,6 \pm 11,4 \\
t=-1,563 \\
p=0,119\end{array}$ \\
\hline $\begin{array}{l}\text { Age } \\
25 \text { and below } \\
26 \text { and above }\end{array}$ & $\begin{array}{l}243(60,4) \\
159(39,6)\end{array}$ & $\begin{array}{l}22,9 \pm 5,6 \\
25,7 \pm 3,6 \\
t=-6,091 \\
\mathbf{p}<\mathbf{0 , 0 0 1}\end{array}$ & $\begin{array}{l}71,2 \pm 9,9 \\
77,3 \pm 10,8 \\
t=-5,677 \\
\mathbf{p}<\mathbf{0 , 0 0 1}\end{array}$ \\
\hline $\begin{array}{l}\text { Educational background } \\
\text { Primary school or below } \\
\text { High School or above }\end{array}$ & $\begin{array}{l}89(22.1) \\
313(77.9)\end{array}$ & $\begin{array}{l}22 \pm 5,3 \\
24,6 \pm 4,9 \\
\mathrm{t}=-4,086 \\
\mathbf{p}<\mathbf{0 , 0 0 1}\end{array}$ & $\begin{array}{l}70,9 \pm 9,9 \\
74,5 \pm 10.8 \\
t=-2,944 \\
\mathbf{p}=\mathbf{0 , 0 0 4}\end{array}$ \\
\hline $\begin{array}{l}\text { Employment } \\
\text { Employed } \\
\text { Not Employed }\end{array}$ & $\begin{array}{l}207(51.5) \\
195(48.5)\end{array}$ & $\begin{array}{l}24,9 \pm 4,9 \\
23,1 \pm 5,1 \\
t=3,552 \\
\mathbf{p}=\mathbf{0 , 0 1 8}\end{array}$ & $\begin{array}{l}75,2 \pm 11,6 \\
72,1 \pm 9,4 \\
t=-2,919 \\
\mathbf{p}=\mathbf{0 , 0 0 4}\end{array}$ \\
\hline $\begin{array}{l}\text { How to meet your fiancee } \\
\text { Arranged } \\
\text { Mutual Consent }\end{array}$ & $\begin{array}{l}160(39,8) \\
242(60,2)\end{array}$ & $\begin{array}{l}23,3 \pm 5.2 \\
24,5 \pm 5 \\
t=-2,369 \\
\mathbf{p}=\mathbf{0 , 0 1}\end{array}$ & $\begin{array}{l}72 \pm 9,6 \\
74,9 \pm 11,2 \\
t=-2,747 \\
\mathbf{p}=\mathbf{0 , 0 0 6}\end{array}$ \\
\hline $\begin{array}{l}\text { Mother's educational background } \\
\text { Primary school or below } \\
\text { High School or above }\end{array}$ & $\begin{array}{l}307(76,4) \\
95(23,6)\end{array}$ & $\begin{array}{l}23,3 \pm 5,2 \\
26,4 \pm 3,8 \\
t=-6,304 \\
\mathbf{p}<\mathbf{0 , 0 0 1}\end{array}$ & $\begin{array}{l}72,3 \pm 10,4 \\
78,2 \pm 10,5 \\
t=-4,764 \\
\mathbf{p}<\mathbf{0 , 0 0 1}\end{array}$ \\
\hline $\begin{array}{l}\text { Father's educational background } \\
\text { Primary school or below } \\
\text { High School or above }\end{array}$ & $\begin{array}{l}279(69,4) \\
123(30,6)\end{array}$ & $\begin{array}{l}23,7 \pm 5,3 \\
24,7 \pm 4,6 \\
\mathrm{t}=-1,794 \\
\mathrm{p}=0,074\end{array}$ & $\begin{array}{l}73,7 \pm 10,4 \\
73,8 \pm 11,4 \\
t=-0,083 \\
p=0,934\end{array}$ \\
\hline $\begin{array}{l}\text { Marriage type of mother and father } \\
\text { Arranged marriage } \\
\text { Mutual consent }\end{array}$ & $\begin{array}{l}329(81,8) \\
73(18,2)\end{array}$ & $\begin{array}{l}24,1 \pm 5,2 \\
23,5 \pm 4,6 \\
\mathrm{t}=1,047 \\
\mathrm{p}=0,297\end{array}$ & $\begin{array}{l}73,7 \pm 10,6 \\
74 \pm 11 \\
t=-0,239 \\
p=0,811\end{array}$ \\
\hline $\begin{array}{l}\text { Marriage contract type of mother and father } \\
\text { Only religious marriage } \\
\text { Civil marriage and religious marriage }\end{array}$ & $\begin{array}{l}43(10,7) \\
359(89,3)\end{array}$ & $\begin{array}{l}23 \pm 4,9 \\
24,1 \pm 5,1 \\
\mathrm{t}=-1,327 \\
\mathrm{p}=0,190\end{array}$ & $\begin{array}{l}74,4 \pm 10,8 \\
73,6 \pm 10,7 \\
t=-0,411 \\
p=0,682\end{array}$ \\
\hline $\begin{array}{llll}\text { Obtaining information } & \text { about } & \text { sexual and } \\
\text { reproductive health } & & & \\
\text { Received } & & & \\
\text { Not Received } & & & \end{array}$ & $\begin{array}{l}156(38,8) \\
246(61,2)\end{array}$ & $\begin{array}{l}25,6 \pm 4,7 \\
23 \pm 5 \\
t=5,149 \\
\mathbf{p}<\mathbf{0 , 0 0 1}\end{array}$ & $\begin{array}{l}76,9 \pm 10,7 \\
71,7 \pm 10,2 \\
t=4,730 \\
\mathbf{p}<\mathbf{0 , 0 0 1}\end{array}$ \\
\hline $\begin{array}{l}\text { Persons or places that have provided information } \\
\text { on sexual and reproductive health }(n=156)\end{array}$ & & & \\
\hline
\end{tabular}




\begin{tabular}{|c|c|c|c|}
\hline $\begin{array}{l}\text { TV/Internet/magazine } \\
\text { Healthcare worker } \\
\text { Friends } \\
\text { Family } \\
\text { School }\end{array}$ & $\begin{array}{l}59(37,8) \\
27(17,3) \\
50(32,1) \\
5(3,2) \\
15(9,6)\end{array}$ & $\begin{array}{l}24,7 \pm 4,9 \\
24,3 \pm 3,7 \\
24,6 \pm 5,1 \\
25,6 \pm 3,7 \\
24,7 \pm 3,1 \\
F=0,088 \\
p=0,986\end{array}$ & $\begin{array}{l}74,3 \pm 11,5 \\
76,7 \pm 11,1 \\
76,5 \pm 10,8 \\
80,2 \pm 16,2 \\
78,8 \pm 14,2 \\
\mathrm{~F}=0,732 \\
\mathrm{p}=0,572\end{array}$ \\
\hline $\begin{array}{l}\text { Idea of "Giving education to young people about } \\
\text { sexual and reproductive health causes early } \\
\text { sexual activity" } \\
\text { Agree } \\
\text { Disagree }\end{array}$ & $\begin{array}{l}99(24,6) \\
303(75,4)\end{array}$ & $\begin{array}{l}24,7 \pm 5,1 \\
23,8 \pm 5,1 \\
\mathrm{t}=1,666 \\
\mathrm{p}=0,097\end{array}$ & $\begin{array}{l}75 \pm 12,1 \\
73,3 \pm 10,2 \\
t=1,200 \\
p=0,232\end{array}$ \\
\hline $\begin{array}{l}\text { Feeling under pressure about sexuality } \\
\text { Yes } \\
\text { No }\end{array}$ & $\begin{array}{l}174(43,3) \\
228(56,7)\end{array}$ & $\begin{array}{l}22,7 \pm 5,2 \\
25 \pm 4,7 \\
\mathrm{t}=-4,342 \\
\mathbf{p}<\mathbf{0 , 0 0 1}\end{array}$ & $\begin{array}{l}71,3 \pm 9,4 \\
75,6 \pm 11,3 \\
t=-4,111 \\
\mathbf{p}<\mathbf{0 , 0 0 1}\end{array}$ \\
\hline $\begin{array}{l}\text { Having difficulties in talking about sexual issues } \\
\text { freely } \\
\text { Yes } \\
\text { No }\end{array}$ & $\begin{array}{l}242(60,2) \\
160(39,8)\end{array}$ & $\begin{array}{l}23,3 \pm 5,2 \\
25,1 \pm 4,6 \\
\mathrm{t}=-3,370 \\
\mathbf{p}<\mathbf{0 , 0 0 1}\end{array}$ & $\begin{array}{l}72,7 \pm 10,2 \\
75,2 \pm 11,2 \\
t=-2,216 \\
\mathbf{p}=\mathbf{0 , 0 2 4}\end{array}$ \\
\hline
\end{tabular}

$t=$ independent sample $t$ test, $S D=$ Standard Deviation

Mean scores and Cronbach's alpha values for subdimensions of SBATM-HBM were calculated. The mean score of the perceived benefits is $27,5 \pm 5$, the mean score of the perceived severity is $11,5 \pm 6,6$, the mean score of the perceived susceptibility is $3,0 \pm 1,0$, the mean score of the evaluation as a tool is $22,4 \pm 4,9$ and lastly, the mean score of the perceived barriers is $12,9 \pm 2,2$.
The Cronbach alpha coefficients, which indicate the reliability of the scale, range from 0.75 to 0.97 in the subdimensions, confirming that the scale is highly reliable. The mean score of FBCSI has been found to be $24 \pm 5,1$ while the Cronbach's alpha coefficient has been determined as 0.76 (Table 2).

Table 2. The mean scores of Beliefs Related to Sexual Information (FBRSI) and the Scale of Beliefs and Attitudes Towards Marriage - Health Belief Model (SBATM-HBM) and distribution of Cronbach's alpha coefficients $(n=402)$

\begin{tabular}{|l|l|l|l|}
\hline Scale & $\begin{array}{l}\text { Number of } \\
\text { Items }\end{array}$ & $\begin{array}{l}\text { Mean } \pm \text { SD } \\
\text { Cronbach's } \\
\text { Alfa } \\
\text { Coefficient }\end{array}$ \\
\hline $\begin{array}{l}\text { The Scale of Beliefs and Attitudes Towards Marriage - } \\
\text { Health Belief Model (SBATM-HBM) } \\
\text { The perceived benefits } \\
\begin{array}{l}\text { The perceived severity } \\
\text { The perceived susceptibility }\end{array}\end{array}$ & 8 & $74(10,6)$ & 0,77 \\
The perceived barriers & 5 & $27,5(5)$ & 0,75 \\
\hline The Form of Beliefs Related to Sexual Information (FBRSI) & 34 & $11,5(6,6)$ & 0,80 \\
& 6 & $22,4(4,9)$ & 0,84 \\
& & $24,9(2,2)$ & 0,97 \\
\hline
\end{tabular}


A weak, positive, statistically significant relationship has been found between the Form of Beliefs Related to Sexual Information (FBRSI) scores and the Scale of Beliefs and Attitudes Towards Marriage - Health Belief Model (SBATM - HBM) scores $(\mathrm{p}<0,001$, Table 3$)$.
When the mean score of the Scale of Beliefs and Attitudes Towards Marriage - Health Belief Model (SBATM-HBM) and the effects of various factors are considered, it has been obviously seen that beliefs and attitudes towards marriage are tend to be negative in those who are under 25 or below, have not been informed about sexual and reproductive health, have mothers with a primary school degree or below and have low FBRSI scores. The determinants of these variables have been assessed by calculating Adjusted R2, which was found to be $19.5 \%$ (Table 4).

Table 3. Correlation analysis between the form of Beliefs Related to Sexual Information (FBRSI) scores and the scale of Beliefs and Attitudes Towards Marriage - Health Belief Model (SBATM-HBM) scores

\begin{tabular}{|l|l|l|l|}
\hline & Mean \pm SD & r & $\boldsymbol{p}$ \\
\hline The Form of Beliefs Related to Sexual Information (FBRSI) & $24 \pm 5,1$ & & \\
\hline $\begin{array}{l}\text { The Scale of Beliefs and Attitudes Towards Marriage - Health Belief } \\
\text { Model (SBATM-HBM) }\end{array}$ & $73,7 \pm 10,7$ & 0,374 & $<0,001$ \\
\hline
\end{tabular}

r, Pearson correlation coefficient

Table 4. Analysis of the mean scores of the scale of Beliefs and Attitudes Towards Marriage - Health Belief Model (SBATM-HBM) and the effect of various factors with stepwise multiple linear regression analysis

\begin{tabular}{|c|c|c|c|c|c|c|c|}
\hline \multirow{2}{*}{$\begin{array}{l}\text { The Scale of Beliefs and Attitudes } \\
\text { Towards Marriage - Health Belief } \\
\text { Model (SBATM-HBM) }\end{array}$} & & \multirow{2}{*}{$\begin{array}{l}\text { Std. } \\
\text { Error }\end{array}$} & \multirow[t]{2}{*}{ Std. $\beta$} & \multicolumn{2}{|c|}{$\% 95 \mathrm{Cl}$} & \multirow[t]{2}{*}{$\mathbf{t}$} & \multirow[t]{2}{*}{$p$} \\
\hline & & & & $\begin{array}{l}\text { Low } \\
\text { Value }\end{array}$ & $\begin{array}{l}\text { High } \\
\text { Value }\end{array}$ & & \\
\hline Age & 3,850 & 1,022 & 0,176 & 1,840 & 5,860 & 3,766 & 0,000 \\
\hline $\begin{array}{l}\text { Obtaining information on sexual } \\
\text { and reproductive health }\end{array}$ & $-2,706$ & 1,040 & $-0,123$ & $-4,750$ & $-0,663$ & $-2,603$ & 0,010 \\
\hline Educational background of mother & $-2,856$ & 1,198 & $-0,113$ & $-5,210$ & $-0,501$ & $-2,385$ & 0,018 \\
\hline $\begin{array}{l}\text { The Form of Beliefs Related to } \\
\text { Sexual Information (FBRSI) }\end{array}$ & 0,560 & 0,102 & 0,267 & 0,359 & 0,761 & 5,483 & 0,000 \\
\hline $\mathrm{R}=\mathbf{0 , 4 5 0}$ & \multicolumn{3}{|c|}{$R^{2}=0,203$} & \multicolumn{4}{|c|}{ Adjusted $R^{2}=0,195$} \\
\hline
\end{tabular}

*It has been done with Stepwise Multiple Linear Regression Analysis. The variables with significant contributions to the model have been taken.

**Statistically significant variables (sex, age, educational background, employment status, how to meet with the fiancé, mother's educational background, source of information about sexual and reproductive health, feeling under pressure about sexuality, having difficulty in talking about sexual issues, and lastly, the mean score of the the Form of Beliefs Related to Sexual Information (FBRSI) ) have been included in the multiple regression analysis. As a result of the analysis, variables such as sex, educational background, employment status, how to meet with the fiancé, feeling pressure about sexuality and having difficulty in speaking about sexuality have been eliminated. Finally, the mean score of FBRSI has been analyzed as a continuous variable and other variables have been used as dummy variables. 


\section{DÍSCUSSION}

In the study, it has been determined that the mean score of the women on FBRSI and SBATM-HBM is lower than that of men. Some studies showed that the sexual knowledge of women is lower and, their beliefs and attitudes towards marriage is less favorable than that of men, 14,16 which is precisely consistent with our results. This suggests that in our country where sexuality is taboo, especially women do not have sufficient knowledge about sexuality.

Couples who are 26 years old and above, have high school degree or above, work in an income-generating business, have mother with a high school degree or above and decide to have a mutual consent for marriage are likely to have higher mean scores of FBRSI and SBATM-HBM. In the study of Torun et al., apparent relationship between believing in sexual myths and educational background revealed: as the level of education increases, the level of believing in sexual myths decrease. 17 Some studies investigating the mother's views on sexual education of children, showed that both sexes are more informed by mothers.16,17 For this reason, it is considered that couples whose mothers are working may be more comfortable in talking about sexual issues in the family settings and provide a certain degree of sexual education at home due to their higher educational and cultural levels. Last but not least, as the education level of the individuals increases, they experience less difficulty in accessing the information they need.

It is asserted in the literature that one of the most important requirements of engaged couples is to get accurate information from appropriate sources on sexuality and reproductive health. In this respect, it is also important to know the source of information about sexuality and reproductive health.18 These findings explain both our first and third research questions. In the study with this context, it is seen that one-third of the couples have been informed about sexuality and reproductive health. When the sources from which couples have learnt about sexuality and reproductive health are examined; $37,8 \%$ of them have been informed by mass media, $32,1 \%$ have obtained knowledge from their friends and $17,3 \%$ have learnt from healthcare workers. When the study findings are compared with similar studies, it has been reported that individuals often receive sexual information about sexual issues mostly from friends, visual media, and family members.16,19 For this reason, it is thought that it is important to use mass media effectively in sexual and reproductive health education for couples preparing for marriage. In addition, receiving a low amount of information from the healthcare workers in this reserach is a negative result to deal with. This is because one of the most important tasks of healthcare professionals, especially mid-wives and nurses who have the most interaction with couples preparing for marriage, is to inform and educate the individuals for the required matters. It is definitely considered that the accurate and effective informing of the couples who are in the process of marriage preparation by the healthcare personnel will contribute positively to the prevention of the sexual problems to be experienced in the future.

In the literature, it is stated that sexual education of individuals will contribute to the development of skills such as maturity and sexuality, developing positive values and attitudes, and making more rational and responsible choices in sexual behaviors.10 It is noteworthy that onefourth of the couples in the study think that sexual education given to young people will cause early sexual activity. Studies revealed that individuals who have received sexual education show more responsible sexual behaviours and that they start sexual intercourse at an older age.20 In addition, education and councelling of couples preparing for marriage regarding sexuality and reproductive health may limit the fear and prevent mistakes decrease sexual reluctance and problems that they may bring. It is also stated in the literature that marriage adjustment levels of couples participating in the premarital sexual education program are found to be higher.10, 21

These findings explain both our first and third research questions. In our study, we found a weak positive correlation between the scores of sexual knowledge of the couples and their belief and attitude scores related to marriage. Furthermore, in the study conducted by Vural and Temel (2010), it was determined that the level of sexual knowledge is increased in couples who participated in a pre-marital sexual counselling program as well as their scores of beliefs and attitudes towards marriage. These findings clarify our second research question. 


\section{Conclusion and Recommendations}

When the mean scores of FBRSI and SBATMHBM for engaged couples are examined, it is found that women's marital and sexual information is significantly deficiencient and inadequate when compared to that of men. In the study, it has been determined that those couples who are over 26 years old, have high school degree or above, work in an income-generating business, decide to have a mutual consent for marriage, have a mother with a high school degree or above, and have learnt about sexual and reproductive health have higher mean scores of FBRSI and SBATM-HBM. Additionally, the study has found that one-third of the couples have received information about sexuality and reproductive health; however, very few of them have obtained this information from healthcare workers. It is a noteworthy result of this study that one-fourth of the couples think that giving sexual education to young people will cause early sexual activity. Morover, the couples who have difficulty in talking about sexual issues and feeling pressure about sexuality are found to have significantly lower mean scores of FBRSI and SBATM-HBM. As the couples' mean scores of FBRSI increase, their mean scores of SBATM-HBM increase. Last but not least, it has been found that those couples who are 26 years old or above, are informed about sexual and reproductive health, have a mother with a high school education degree or above, and have high mean scores of FBRSI have a positive effect on their beliefs and attitudes towards marriage.

In the light of these results, the following suggestions can be made:

When the results of the research are taken into consideration, in order to organize the sexual education counselling programs before marriage effectively, the candidates' beliefs and attitudes towards marriage and their needs of knowledge in sexual matters should be taken into consideration. Future studies that are carried out in different cities, with different educational levels, on different ethnic and socioeconomic structures could increase the generalizability of the information obtained. All in all, considering the cultural characteristics of the society, it is believed that sexual counselling to be given to couples and individuals before marriage may provide them with a hassle-free, satisfactory sexual life experience and happy marriage, renewing their false information and beliefs.

\section{REFERENCES}

1. Al Azeem STA, Eman TE, Naglaa AEKES, Lamiaa AEGA. Promotion of knowledge and attitude towards premarital care: An interventional study among medical student in Fayoum University. Journal of Public Health and Epidemiology 2011:3(3):121-128.

Available online at http://www.academicjournals.org/jphe.

2. Moodi M, Miri MR, Sharifirad GR. The effect of instruction on knowledge and attitude of couples attending premarriage counseling classes. Journal of Education and Health Promotion 2013(2). https://doi.org/10.4103/2277-9531.119038.

3. Khazaeia M, Rostamib R, Zaryabic A. The Relationship between sexual dysfunctions and marital satisfaction in Iranian married students Procedia. Social and Behavioral Sciences 2011;30:783-785. https://doi.org/10.1016/j.sbspro.2011.10.1 52

4. Avc1, N. Beji N. Sexuality in Society, Affecting Factors. Androloji Bülteni 2011;45:155-159. Available from: http://file.lookus.net/androlojibulteni/Hazir an-2011-45.Say\%C4\%B1.pdf

5. Akın A, Özvarış B. (2003). Adölesanların cinsel ve üreme sağlığını etkileyen faktörler projesi. Retrieved May 11, 2016:1-183. Available from: http://www.huksam.hacettepe.edu.tr/Turkc e/SayfaDosya/ adolesan.pdf. Erişim tarihi: 4 Kasim 2018.

6. Vefikuluçay D, Zeyneloğlu S, Eroğlu K, Taşkın L. Kafkas Üniversitesi son sınıf öğrencilerinin toplumsal cinsiyet rollerine ilişkin bakış açıları [Perception of and Views on Gender Roles of Senior Students Enrolled at Kafkas University]. HÜ Hemşirelik Yüksekokulu Dergisi 2007;14(2):26-38. Available from: http://dergipark.gov.tr/download/articlefile $/ 88570$

7. Yılmaz A, Tanrıverdi HM, Gücük S, Akan Z. Contraception knowledge status of marriage applicants couples in the Van city. Dicle Tip Dergisi 2013;40(3):453457. doi: 10.5798/diclemedj.0921.2013.03.0309.

8. Timur S. Sexuality and societies' view of sexuality. İnönü Üniversitesi Sağlık Hizmetleri Meslek Yüksekokulu Dergisi 2010;(1):65-75. Available from: http://dergipark.gov.tr/inonusaglik/archive

9. Doğan S, Saraçoğlu VG. The Assessment of Sexual Knowledge, Marital 
Characteristics, Sexual Function and Satisfaction in Women with Lifelong Vaginismus. Trakya Üniversitesi Tip Fakültesi Dergisi 2009;26(2):151-158. Available from: https://www.researchgate.net/publication/2 6635033

10. Kalkan M, Ersanlı E. The Effect of Cognitive-Behavioral Approach-Based Marriage Relationship Development Program on Marital Adjustment of Married Individuals. Kuram ve Uygulamada Eğitim Bilimleri 2008;8:963986. Available from: https:/www.researchgate.net/profile/Ercue mend_Ersanli/publication/288393036_The Effects_of_the_Marriage_Enrichment_Pr ogram_Based_on_the_Cognitive-

Behavioral_Approach_on_the_Marital_Ad

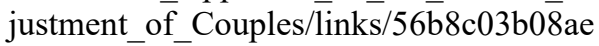
$9 \mathrm{e} 2112 \mathrm{bb} 02 \mathrm{fb} /$ The-Effects-of-the-

Marriage-Enrichment-Program-Based-onthe-Cognitive-Behavioral-Approach-onthe-Marital-Adjustment-of-Couples.pdf

11. Char A, Saavala M, Kulmala T. Assessing young unmarried men's access to reproductive health information and services in rural India. BMC Public Health 2011;11(476):1-10. https://doi. org/10.1186/1471-2458-11-476.

12. Şentürk GE. Ortaöğretim kurumlarına devam eden öğrenciler ile bu kurumda çalışan öğretmenler ve yöneticilerin cinsellikle ilgili yanlış inanışla bilgi ve inanışlarının belirlenmesi ve bir uygulama. Marmara Üniversitesi Eğitim Bilimleri Enstitüsü Yüksek Lisans Tezi. İstanbul. 2006:1-138 Available from: https:/tez.yok.gov.tr/UlusalTezMerkezi/te zSorguSonucYeni.jsp. Erişim tarihi: 22Aralık 2018.

13. Sullivan TK, Pasch L, Cornelıus T. et al. Predicting Participation in Premarital Prevention Programs: The Health Belief Model and Social Norms, Family Process. Health \& Medical Complete 2004:43(2);175-193.

https://doi.org/10.1111/j.1545-

5300.2004.04302004.x

14. Vural BK, Temel AB. Beliefs and attitudes towards marriage: analysis of validity and reliability of health belief model instrument for Turkish society. Ege Üniversitesi Hemşirelik Yüksek Okulu Dergisi 2007: 23(2): 31-50. Available from:

http://dergipark.gov.tr/download/issuefile/10090

15. Alpar R. Spor sağlik ve eğitim bilimlerinden örneklerle uygulamalı istatistik ve geçerlik güvenirlik. 5. Baskı. Ankara: Detay Yayıncılık; 2018. p. 130-4. (Turkish)

16. Kısa S, Zeyneloğlu S, Yılmaz D, Verim E. Knowledge and beliefs related to sexuality of couples doing marriage preparation. TAF Preventive Medicine Bulletin 2013;12(3): 297-306. Available from: https://www.ejmanager.com/mnstemps/1/1 -1341926050.pdf

17. Torun F, Torun SD, Özaydın AN. Men's Belief in Sexual Myths and Factors Effecting These Myths. Düşünen Adam The Journal of Psychiatry and Neurological Sciences 2011;24:24-31. DOI: $10.5350 / D A J P N 2011240103$.

18. Dzara K. Assessing the effect of marital sexuality on marital disruption. Social Science Research 2010;39: 715-724. https://doi.org/10.1016/j.ssresearch.2010.0 6.003 .

19. Y1lmaz E, Zeytinci İE, Sarı S, Karababa IF, Çilli AS, Kucur R. Investigation of sexual problems in married population living in the center of Konya. Türk Psikiyatri Dergisi 2010; 1-8. Available from:

https://www.researchgate.net/profile/Ertan _Yilmaz2/publication/44641631_Investiga tion_of_Sexual_Problems_in_Married_Pe ople_Living_in the_Center_of_Konya/lin $\mathrm{ks} / 0 \overline{0} \mathrm{~b} 4953123 \overline{\mathrm{faea}} 14 \mathrm{e} 00000 \overline{0} /$ Investigati on-of-Sexual-Problems-in-Married-

People-Living-in-the-Center-of-Konya.pdf

20. Çalışandemir F, Bencik S, Artan İ. Sexual Education of Children: An Overview from the Past to Present. Education and Science 2008;33(150):14-27. Available from: https://search.proquest.com/openview/ddf3 2ff484e6bdd72827cea643977402/1?pqorigsite $=$ gscholar\&cbl $=1056401$

21. Çă̆ P, Yıldırım İ. Relational and personal predictors of marital satisfaction. Türk Psikolojik Danışma ve Rehberlik Dergisi 2013;4(39):13-23. Available from: http://www.acarindex.com/dosyalar/makal e/acarindex-1423931694.pdf 